$(\mathrm{R})-21^{13},(\mathrm{R})-35^{14},(\mathrm{R})-37^{12}$, Ginsenoside $\mathrm{Rg} 1^{15}$ and Org $214007-0^{16}$. Results are shown in Table 1. (R)-16 showed better efficacy and safety compared to prednisone. Compound A, Ginsenoside Rg 1, Compounds 14, (R)-18, and (R)-21 had better safety profiles than a GC, but with similar efficacy. (R)-35 and (R)-37 showed better efficacy than a GC, but safety data was lacking. Org 214007-0, LGD-5552, Compounds 4 and 5 and PF-04171327 showed similar efficacy as a $\mathrm{GC}$, but no safety data was provided.

\begin{tabular}{|c|c|c|c|c|c|c|c|c|}
\hline $\begin{array}{l}\text { Author, } \\
\text { year }\end{array}$ & $\begin{array}{l}\text { SGRM } \\
\text { tested }\end{array}$ & $\begin{array}{c}\text { Reference } \\
\text { compoun } \\
\mathrm{d}\end{array}$ & $\begin{array}{l}\text { Clinical } \\
\text { trial }\end{array}$ & $\begin{array}{l}\text { Pre- } \\
\text { clinical } \\
\text { human }\end{array}$ & $\begin{array}{l}\text { Pre- } \\
\text { clinical } \\
\text { animal }\end{array}$ & Efficacy & Safety & $\begin{array}{l}\text { Conclusion on efficacy and } \\
\text { safety in comparison to } \\
\text { reference compound }\end{array}$ \\
\hline $\begin{array}{l}\text { Dewint et } \\
\text { al., 2008 }\end{array}$ & $\begin{array}{l}\text { Compound } \\
\text { A }\end{array}$ & Dex & & $\mathrm{x}$ & $x$ & $x$ & $x$ & $\begin{array}{l}\text { Similar efficacy. Better saffety } \\
\text { of Compound A. }\end{array}$ \\
\hline $\begin{array}{l}\text { Gossye et } \\
\text { al., 2009 }\end{array}$ & $\begin{array}{l}\text { Compound } \\
\text { A }\end{array}$ & Dex & & $x$ & & & & $\begin{array}{c}\text { Similar efficacy. No safety } \\
\text { data }\end{array}$ \\
\hline $\begin{array}{l}\text { Gossye et } \\
\text { al., } 2010\end{array}$ & \begin{tabular}{|l} 
Compound \\
A
\end{tabular} & Dex & & $\mathrm{x}$ & $x$ & & & $\begin{array}{l}\text { Less efficacy of Compound } A \text {. } \\
\text { No safety data. }\end{array}$ \\
\hline $\begin{array}{l}\text { Rauch et } \\
\text { al., } 2011\end{array}$ & $\begin{array}{l}\text { Compound } \\
\text { A }\end{array}$ & Dex & & $x$ & & $\mathrm{x}$ & $x$ & $\begin{array}{l}\text { Similar efficacy. Better safety } \\
\text { of Compound A. }\end{array}$ \\
\hline $\begin{array}{l}\text { Rauner et } \\
\text { al., } 2013\end{array}$ & $\begin{array}{l}\text { Compound } \\
\text { A }\end{array}$ & Dex & & & $x$ & $x$ & $x$ & $\begin{array}{l}\text { Less efficacy of Compound A. } \\
\text { Better safety of Compound A }\end{array}$ \\
\hline $\begin{array}{l}\text { Malaise et } \\
\text { al., } 2015\end{array}$ & $\begin{array}{l}\text { Compound } \\
\text { A }\end{array}$ & Pred & & $x$ & & $x$ & $x$ & $\begin{array}{l}\text { Similar efficacy. Better safety } \\
\text { of compound } A \text {. }\end{array}$ \\
\hline $\begin{array}{l}\text { Yang et al., } \\
2015\end{array}$ & $\begin{array}{l}\text { Compound } \\
4 \text { and } 5\end{array}$ & Pred & & & $x$ & $x$ & & $\begin{array}{l}\text { Similar efficacy of compound } \\
\text { 4, better efficacy of } \\
\text { compound 5. No safety data. }\end{array}$ \\
\hline $\begin{array}{l}\text { Razavi et } \\
\text { al., 2014 }\end{array}$ & \begin{tabular}{|l} 
Compound \\
14
\end{tabular} & Pred & & & $x$ & $x$ & $x$ & $\begin{array}{l}\text { Similar efficacy. Better safety } \\
\text { of Compound } 14 \text {. }\end{array}$ \\
\hline $\begin{array}{l}\text { Riether et } \\
\text { al., } 2010\end{array}$ & $\begin{array}{l}\text { Compound } \\
\text { (R) }-16 \text { and } \\
\text { (R) }-37\end{array}$ & Pred & & & $x$ & $x$ & $x$ & $\begin{array}{l}\text { Better efficacy of (R)-16. } \\
\text { Better safety of (R)-16 and } \\
\text { (R) }-37 \text {. }\end{array}$ \\
\hline $\begin{array}{l}\text { Harcken et } \\
\text { al., } 2014\end{array}$ & $\begin{array}{l}\text { Compound } \\
\text { (R)-18 and } \\
(\mathrm{R})-21\end{array}$ & Pred & & & $\mathrm{x}$ & $\mathrm{x}$ & $x$ & $\begin{array}{l}\text { Similar efficacy. Better safety } \\
\text { of } R)-18 \text { and }(R)-21 \text {. }\end{array}$ \\
\hline $\begin{array}{l}\text { Weinstein } \\
\text { et al., } 2011\end{array}$ & \begin{tabular}{|l|} 
Compound \\
35 and 37 \\
\end{tabular} & Pred, dex & & & $\mathrm{x}$ & $x$ & & $\begin{array}{l}\text { Better efficacy of compounds } \\
35 \text { and } 37 \text {. No safety data. }\end{array}$ \\
\hline $\begin{array}{l}\text { Miner et } \\
\text { al., } 2007\end{array}$ & LGD-5552 & Pred & & & $x$ & $x$ & & $\begin{array}{l}\text { Similar efficacy. No safety } \\
\text { data. }\end{array}$ \\
\hline $\begin{array}{l}\text { Lopez et } \\
\text { al., } 2008\end{array}$ & LGD-5552 & Pred & & & $x$ & $x$ & & $\begin{array}{l}\text { Similar efficacy. No safety } \\
\text { data. }\end{array}$ \\
\hline $\begin{array}{l}\text { Du et al., } \\
2011\end{array}$ & $\begin{array}{l}\text { Ginsenoside } \\
\text { Rg1 }\end{array}$ & Dex & & & $x$ & $x$ & & $\begin{array}{l}\text { Similar efficacy. Better safety } \\
\text { of Ginsenoside Rg1. }\end{array}$ \\
\hline $\begin{array}{l}\text { Van Lierop } \\
\text { et al., } \\
2012\end{array}$ & $\begin{array}{l}\text { Org } \\
214007 \cdot 0\end{array}$ & Pred & & & $\mathrm{x}$ & $\mathrm{x}$ & $x$ & $\begin{array}{l}\text { Similar efficacy of org- } \\
214007-0 . \text { No safety data. }\end{array}$ \\
\hline $\begin{array}{l}\text { Conrado et } \\
\text { al., } 2015\end{array}$ & \begin{tabular}{|l|} 
PF- \\
04171327
\end{tabular} & Pred & $\mathrm{x}$ & & & $\mathrm{x}$ & & $\begin{array}{l}\text { Similar efficacy. No safety } \\
\text { data. }\end{array}$ \\
\hline
\end{tabular}

Conclusions: Studies both assessing efficacy and safety parameters of SGRMs are scarce. Currently, there is insufficient evidence for the presumed superior efficacy/toxicity balance of SGRMs compared to that of GCs.

References:

[1] Dewint P et al. J Immunol. 2008;180:2608-15.

[2] Rauch A et al. FASEB J. 2011;25:1323-32.

[3] Rauner M et al. Endocrinology. 2013;154:3719-28.

[4] Malaise O et al. Rheumatology. 2015;54:1087-92.

[5] Gossye V et al. Arthritis Rheum. 2009;60:3241-50.

[6] Gossye V et al. Ann Rheum Dis. 2010;69:291-6.

[7] Conrado DJ et al. J Pharmacokinet Pharmacodyn. 2016;43:325-41.

[8] Miner JN et al. Proc Natl Acad Sci U S A. 2007;104:19244-9.

[9] López et al. Endocrinology. 2008;149:2080-9.

[10] Yang MG et al. J Med Chem. 2015;58:4278-90.

[11] Razavi $\mathrm{H}$ et al. Bioorg Med Chem Lett. 2014;24:1934-40.

[12] Riether D et al. J Med Chem. 2010;53:6681-98.

[13] Harcken C et al. J ed Chem. 2014:57:1583-98.

[14] Weinstein DS et al. J Med Chem. 2011;54:7318-33.

[15] Du J et al. J Immunol. 2011;187:942-50.

[16] Van Lierop MJ et al. PLoS One.2012;7:e48385.

Disclosure of Interest: M. Safy Grant/research support from: MS was supported by a research grant from Astra Zeneca. Astra Zeneca was not involved in this study., M. De Hair: None declared, J. Jacobs: None declared, F. Buttgereit: None declared, M. Kraan: None declared, J. van Laar: None declared

DOI: 10.1136/annrheumdis-2017-eular.3254

\section{AB0429 SHORT-TERM EFFECTS OF LOW DOSE GLUCOCORTICOIDS ON BONE METABOLISM IN EARLY RHEUMATOID ARTHRITIS}

M. Vitiello ${ }^{1}$, O. Viapiana ${ }^{1}$, N. Malavolta ${ }^{2}$, G. Saviola $^{3}$, R. Bortolotti ${ }^{4}$

L. Idolazzi $^{1}$, F. Bertoldo ${ }^{1}$, G. Orsolini ${ }^{1}$, M. Risoli ${ }^{1}$, D. Gatti ${ }^{1}$, M. Rossini ${ }^{1}$.

${ }^{1}$ Rheumatology Unit, University of Verona, Verona; ${ }^{2}$ Rheumatology Unit, AOU of Bologna, Bologna; ${ }^{3}$ Rheumatology and Rehabilitation Unit, Salvatore Maugeri Foundation IRCCS, Castel Goffredo, Mantua; ${ }^{4}$ Rheumatology Unit, Santa Chiara Hospital, Trento, Italy

Background: Glucocorticoids (GCs) are frequently used in the treatment of Rheumatoid Arthritis (RA). Studies in humans about the effects on bone turnover markers and modulators are poor, and results are discordant and controverse, probably because conducted with different doses and underlying diseases.

Objectives: To evaluate changes in serum bone turnover markers and Wnt inhibitors at 7- and 30-days after initiation of low dose GCs treatment of early RA. Methods: 27 adult patients suffering from early RA were prospectively enrolled. Blood tests including C-Reactive Protein (CRP), amino-terminal propeptide of type 1 procollagen (P1NP, marker of bone formation), carboxy-terminal telopeptide of type 1 collagen (CTX, marker of bone resorption), Sclerostin, and Dickkopf-related protein 1 (DKK1) were detected at baseline and 7 and 30 days after starting low dose of GC (methylprednisolone $4 \mathrm{mg} /$ day).

Results: At baseline we observed a significant positive correlation between CRP and DKK1 serum levels $(r=0,63 ; p<0,05)$ and between DKK1 and CTX serum levels $(r=0,38 ; p<0,05)$. A significant decrease in serum levels of CRP, P1NP, and Sclerostin was observed after 7 and 30 days of GC treatment $(p<0,05)$. About DKK1, it has been detected a not significant tendency to decrease after starting GC. CTX serum levels showed no significant changes.

Conclusions: This study has shown that a low dose GC treatment might have complex and conflicting short-term effects on bone metabolism in early RA (a reduction of bone formation, without increase of bone resorption), different from those observed with higher dose, in other diseases or in healthy subjects. The observed decrease in P1NP and Sclerostin serum levels might mean that also low dose of GC could acutely suppress bone formation and induce loss of function and/or number of osteocytes.

Disclosure of Interest: None declared

DOI: 10.1136/annrheumdis-2017-eular.4667

\section{AB0430 LEFLUNOMIDE AS A SECOND LINE DMARD AFTER METHOTREXATE HAS LIMITED IMPACT ON RHEUMATOID ARTHRITIS IN REAL LIFE}

G. Weigt, A. Erler, M. Aringer. Medicine III, University Medical Center TU Dresden, Dresden, Germany

Background: If rheumatoid arthritis (RA) is not in remission or at least low disease under methotrexate (MTX), leflunomide is an approved conventional synthetic DMARD, which is commonly used in some countries.

Objectives: To investigate in a real life situation whether patients with RA benefit from instituting leflunomide after methotrexate.

Methods: The clinical data of all RA patients who had at least once received leflunomide, and who agreed to the pseudonymized analysis of their data (approved by the local ethics committee), were analyzed from the time of leflunomide initiation on to the time of stopping leflunomide or the last visit in 2015, which ever came first.

Results: In total, 145 RA patients treated with leflunomide were identified. Of these, 87 received leflunomide after MTX had failed as a first line DMARD, and 8 received leflunomide as a first line DMARD. 50 patients had another first line therapy. Of the first line leflunomide patients $3(38 \%)$ were still on leflunomide at the last visit, as compared to 7 of the 44 patients $(16 \%)$ who were switched from MTX to leflunomide, and 0 of the 27 patients in whom leflunomide was added to MTX ( $p<0.01$ vs 1 st line leflunomide). For leflunomide monotherapy, $29 \%$ and $19 \%$ were still on the drug after 24 and 48 months, respectively, as compared to 14 and $0 \%$ under the combination with MTX. Of all patients who started leflunomide, remission (at least low disease activity) as per CDAI $(\leq 2.8(\leq 10))$ was reached by $23 \%$ (57\%) 3 months, $20 \%$ (40\%) 6 months, and $16 \%$ (34\%) one year after initiating leflunomide monotherapy, with corresponding percentages of patients of $39 \%$ switched to other approaches at six months and of $60 \%$ switched at one year. Under the combination of leflunomide and MTX, remission (at least low disease activity) was seen in $18 \%(53 \%)$ at 3 months, $20 \%(37 \%)$ at 6 months, and $8 \%(20 \%)$ at one year, and $55 \%$ and $71 \%$ had switched to other modes of action at six months and one year, respectively. Gastrointestinal and mucocutaneous adverse events and hypertension were common, and 4 our patients experienced serious bacterial infections.

Conclusions: Leflunomide constitutes a longer term option for a subgroup of RA patients with contraindications to MTX or after MTX failure. After one year, leflunomide had led to sustained acceptable disease control in approximately one third of the patients, but only in one in five under leflunomide combined with MTX. These results are supportive of the EULAR recommendations that patients should be switched to a second conventional DMARD in the absence of predictors of bad outcome only. If leflunomide is initiated, the patients need to be followed closely for potential secondary loss of efficacy.

Disclosure of Interest: None declared

DOI: 10.1136/annrheumdis-2017-eular.3531

\section{AB0431 POST-MARKETING SURVEILLANCE OF TOFACITINIB IN JAPANESE PATIENTS WITH RHEUMATOID ARTHRITIS: AN INTERIM REPORT OF SAFETY DATA}

T. Mimori ${ }^{1}$, M. Harigai ${ }^{2}$, T. Atsumi ${ }^{3}$, M. Kuwana ${ }^{4}$, S. Takei ${ }^{5}$, N. Tamura ${ }^{6}$, T. Fujii ${ }^{7}$, H. Matsuno ${ }^{8}$, S. Momohara ${ }^{9}$, K. Yamamoto ${ }^{10}$, T. Kokubo $^{11}$, Y. Endo ${ }^{11}$, N. Sugiyama ${ }^{11}$, T. Hirose ${ }^{11}$, Y. Morishima ${ }^{11}$, N. Yoshii ${ }^{11} .{ }^{1}$ Kyoto University, Kyoto; ${ }^{2}$ Tokyo Women's Medical University, Tokyo; ${ }^{3}$ Hokkaido University, Sapporo; ${ }^{4}$ Nippon Medical School, Tokyo; ${ }^{5}$ Kagoshima University, Kagoshima; ${ }^{6}$ Juntendo University, Tokyo; ${ }^{7}$ Wakayama Medical University, Wakayama; ${ }^{8}$ Matsuno Clinic for Rheumatic Diseases, Toyama; ${ }^{9}$ Hakkeikai Inc Medical Institution, Shizuoka; ${ }^{10}$ The University of Tokyo; ${ }^{11}$ Pfizer Japan Inc, Tokyo, Japan

Background: Tofacitinib is an oral JAK inhibitor for the treatment of rheumatoid arthritis (RA). Efficacy and safety of tofacitinib have been shown in RA patients in global Phase 2, Phase 3 (one study included Japanese patients) and long-term extension (LTE) studies and in two Phase 2 and one LTE study in Japanese patients. 
Objectives: We evaluated the safety of tofacitinib following drug approval in Japanese patients with RA using all-case post-marketing surveillance (PMS) data.

Methods: A 6-month interim analysis of safety data from an ongoing 3-year PMS study was conducted (5 Nov 2016 data-cut). All Japanese patients with RA who were treated with tofacitinib were consecutively and prospectively registered in the PMS study and were monitored for all adverse events (AEs) for 3 years. Baseline and follow-up data were collected from booklet-type survey forms. Follow-up surveillance after discontinuation of tofacitinib treatment was implemented: 12 months for serious infections and 3 years for malignancy or AEs leading to death from the date of treatment initiation with tofacitinib. AEs were coded using MedDRA/J.

Results: Overall, 2387 tofacitinib-treated patients were enrolled (1020.0 patientyears [pt-yrs] of exposure); of these, 594 patients (24.9\%) discontinued treatment, mainly due to AEs $(n=236 ; 9.9 \%)$ or lack of effectiveness $(n=225 ; 9.4 \%)$. In total, $1793(75.1 \%)$ patients continued treatment for 6 months. At least one AE was observed in 815 patients $(34.1 \%)$, the most frequent of which was herpes zoster $(n=78 ; 3.3 \%)$, including 12 serious cases. Serious AEs occurred in 190 patients $(8.0 \%)$; the most frequent were pneumonia $(n=20 ; 0.8 \%)$, interstitial lung disease $(n=14 ; 0.6 \%)$ and condition aggravated $(n=13 ; 0.5 \%)$. Infections $(n=304$; $12.7 \%)$ were serious in 88 patients $(3.7 \%)$. Thirteen patients $(0.5 \%)$ reported malignancy, including ovarian cancer $(n=2 ; 0.1 \%)$, diffuse large B-cell lymphoma $(n=2 ; 0.1 \%)$ and lymphoproliferative disorder $(n=1,0.04 \%)$. Sixteen $(0.7 \%)$ deaths were reported.

Conclusions: Interim analyses of AEs during the initial 6-month treatment period from PMS reports of tofacitinib in Japanese patients did not reveal any new or unexpected safety signals vs the tofacitinib RA clinical programme. The target sample size for the final PMS analysis is 6000 patients (4000 tofactinib-treated, 2000 control patients).

Acknowledgements: This study was sponsored by Pfizer Inc. Editorial support was provided by $\mathrm{K}$ Nicholson of CMC and was funded by Pfizer Inc.

Disclosure of Interest: T. Mimori Grant/research support from: Astellas, Ayumi, Chugai, Daiichi-Sankyo, Eisai, Mitsubishi-Tanabe, MSD, Nippon Shinyaku, Takeda, Speakers bureau: Astellas, Bristol-Myers Squibb, Chugai, Eisai, MitsubishiTanabe, M. Harigai Grant/research support from: Bristol-Myers Squibb, Eisai, Eli Lilly, Ono, Takeda, T. Atsumi Grant/research support from: Alexion, Astellas, Bristol-Myers Squibb, Chugai, Eisai, Janssen, Mitsubishi-Tanabe, Sanofi. Scholarship donations from: Bayer, Daiichi-Sankyo, Takeda, Speakers bureau: AbbVie, Astellas, Chugai, Eisai, Mitsubishi-Tanabe, Pfizer Inc, Takeda, UCB Japan, M. Kuwana Grant/research support from: Chugai, Eisai, Mitsubishi-Tanabe, Ono, Pfizer Inc, Santen, Speakers bureau: Astellas, Chugai, Eisai, Janssen, Mitsubishi-Tanabe, Ono, Pfizer Inc, UCB, S. Takei Grant/research support from: Chugai, Eisai, Mitsubishi-Tanabe, Takeda, Speakers bureau: Asahi Kasei, Ayumi, Chugai, Mitsubishi-Tanabe, Ono, N. Tamura Grant/research support from: AbbVie, Astellas, Bristol-Myers Squibb, Chugai, Eisai, Janssen, Mitsubishi-Tanabe, Takeda, Speakers bureau: AbbVie, Astellas, Bristol-Myers Squibb, Eisai, Janssen, Mitsubishi-Tanabe, T. Fujii Grant/research support from: AbbVie, Asahi Kasei, Astellas, Chugai, Eisai, Janssen, Kissei, Mitsubishi-Tanabe, Ono, Pfizer Japan Inc, Taisho Toyama, Takeda, UCB Japan, Speakers bureau: AbbVie, Actelion, Astellas, Ayumi, Chugai, Daiichi-Sankyo, Kissei, Mitsubishi-Tanabe, Nippon Kayaku, Ono, Pfizer Japan Inc, Taisho Toyama, Takeda, H. Matsuno Consultant for: Ayumi, Meiji Seika, Mochida, Nichi-Iko, S. Momohara Speakers bureau: AbbVie, Bristol-Myers Squibb, Eisai, Janssen, Mitsubishi-Tanabe, Ono, Pfizer Japan Inc, Takeda, K. Yamamoto Grant/research support from: AbbVie, Astellas, Ayumi, Chugai, Eisai, Mitsubishi-Tanabe, Nippon Kayaku, Pfizer Japan Inc, Taisho Toyama, Takeda, Teijin, UCB, Speakers bureau: Asahi Kasei, AstraZeneca, Ayumi, Boehringer Ingelheim, Bristol-Myers Squibb, Chugai, Eisai, Janssen, Mitsubishi-Tanabe, Pfizer Inc, Sanofi, Sumitomo Dainippon, Taisho Toyama, Takeda, Teijin, Toyama Chemical, UCB, T. Kokubo Employee of: Pfizer Japan Inc, Y. Endo Shareholder of: Pfizer Inc, Employee of: Pfizer Japan Inc, N. Sugiyama Shareholder of: Pfizer Inc, Employee of: Pfizer Japan Inc, T. Hirose Shareholder of: Pfizer Inc, Employee of: Pfizer Japan Inc, Y. Morishima Shareholder of: Pfizer Inc, Employee of: Pfizer Japan Inc, N. Yoshii Shareholder of: Pfizer Inc, Employee of: Pfizer Japan Inc DOI: 10.1136/annrheumdis-2017-eular.1420

\section{AB0432 ABT-494 HAS NO EFFECT ON THE QT INTERVAL AT THE DOSES BEING EVALUATED IN RHEUMATOID ARTHRITIS PHASE 3 TRIALS}

M.-E.F. Mohamed, J. Zeng, P. Jiang, B. Hosmane, A.A. Othman. Clinical Pharmacology and Pharmacometrics, AbbVie, North Chicago, United States

Background: ABT-494 is a selective Janus Kinase 1 inhibitor currently being evaluated in Phase 3 trials for treatment of rheumatoid arthritis (RA) at doses of $15 \mathrm{mg}$ and $30 \mathrm{mg}$ once daily using the extended-release tablet formulation. Exposure-response analysis of ECG data collected at early stage clinical trials has been recently adopted in regulatory guidelines as a tool to assess the proarrhythmic risk of investigational new drugs.

Objectives: The objective of this work was to evaluate ABT-494 QT prolongation potential using exposure-response analysis of data collected in early Phase 1 studies.

Methods: Doses of ABT-494 or placebo were administered to healthy subjects in two Phase 1 studies. Evaluated ABT-494 immediate-release regimens ranged from $1 \mathrm{mg}$ to $48 \mathrm{mg}$ single doses under fasting conditions and $3 \mathrm{mg}$ to 24 $\mathrm{mg}$ twice daily under non-fasting conditions. Serial triplicate electrocardiograms and pharmacokinetic assessments were conducted. The relationship between change from baseline in Fridericia-corrected QT interval (QTcF) and ABT-494 plasma concentrations was characterized using linear mixed-effects modeling. To evaluate the ECG assay sensitivity, the change in QTcF from baseline to 2 hours post-dose was compared for subjects who received placebo under fasting and non-fasting conditions.

Results: There was no statistically significant relationship between the change from baseline in the QTcF interval and ABT-494 plasma concentrations. The point estimate of the effect on QTcF for the highest concentration observed in the evaluated studies, which is approximately 4 -fold higher than the mean $\mathrm{C}_{\max }$ of the highest RA Phase 3 dose, is $-1.77 \mathrm{msec}$ (with upper bound of the $95 \%$ one-sided confidence interval of $3.33 \mathrm{msec}$; lower than the regulatory threshold of concern of $10 \mathrm{msec}$ ). Food shortened the QTcF interval by $5.9 \mathrm{msec}$ (2-sided $90 \%$ confidence interval of -9.6 to $-2.1 \mathrm{msec}$ ), indicating that the ECG assay used in the studies had adequate sensitivity to detect the small change in QTcF caused by food.

Conclusions: ABT-494 showed no potential for QT prolongation at the expected therapeutic and supra-therapeutic plasma exposures for the doses being used in Phase 3 RA trials.

Disclosure of Interest: M.-E. Mohamed Shareholder of: AbbVie, Employee of: AbbVie, J. Zeng Shareholder of: AbbVie, Employee of: AbbVie, P. Jiang Shareholder of: AbbVie, Employee of: AbbVie, B. Hosmane Shareholder of: AbbVie, Employee of: AbbVie, A. Othman Shareholder of: AbbVie, Employee of: AbbVie DOI: 10.1136/annrheumdis-2017-eular.3230

\section{AB0433 CORRECTION OF LIPID AND ENDOTHELIAL DYSFUNCTION BY USING NO DONATORS (4,2\% SOLUTION OF ARGININE HYDROCHLORIDE AND L-ARGININE ASPARTATE) IN PATIENT WITH RHEUMATOID ARTHRITIS IN COMBINATION WITH THE RAYNAUD'S SYNDROME}

O. Shtefiuk, R. Yatsyshyn. Internal Medicine \#1, Ivano-Frankivsk National Medical University, Ivano-Frankivsk, Ukraine

Background: Lesion of the cardiovascular system is associated with uncontrolled inflammation and immune defects in patients with Rheumatoid Arthritis (RA). There is an evidence of the close pathogenetic connection between rheumatoid inflammation and accelerated development of atherosclerosis. The first sing of atherosclerosis is endothelial dysfunction (ED).

Objectives: Evaluate the effectiveness of NO donators (4,2\% solution of arginine hydrochloride and L-arginine aspartate) in the correction of lipid and ED in patients with RA and secondary Raynaud's syndrome (RS).

Methods: 68 patients with RA were examined. All patients were divided into 2 groups: (37 people with RA in combination with secondary $\mathrm{RS}$ ) received basic therapy of RA (methotrexate $10-15 \mathrm{mg} / \mathrm{wk}$.), antiplatelet and vasodilatory drugs; II group (31 people - RA in combination with secondary RS) got similar therapy plus NO donators $(4,2 \%$ solution of arginine hydrochloride and L-arginine aspartate). The examination was carried out at the patient's admission to the hospital and the hospital and 3 months after the beginning of treatment. Endothelial function was assessed by determining the flow-mediated vasodilation of brachial artery (FMD), levels of endothelin-1, rheumatoid factor (RF), C-reactive protein (CRP), lipid profile (total cholesterol - TC, low density lipoprotein - LDL, highdensitylipoprotein - HDL and triglycerides - TG), index of intima/media (IM) and atherogenic index (AI).

Results: Levels of TC, LDL, Al and MI indexes were significantly higher than the norm in 2 compared groups before the treatment and 3 months after its start $(p<0,05)$. There were significant decreases in levels of lipid profile, IA and $\mathrm{Ml}$ index in II group 3 months after treatment in comparison to benchmarks (TC by $13,3 \%$, LDL by $16,1 \%$, TG by $14,7 \%$, Al index by $13,8 \% \mathrm{MI}$ index by $12,7 \%, p<0,05)$ and they were significantly unchanged in I group $(p<0,05)$. It was elucidated a direct reliable strong correlation in patients of II group between the level of FMD and endothelin-1 before treatment $(r=0,73, p<0,05)$ and after treatment $(r=0,69, p<0,05)$. Symptoms of ED, levels of endothelin-1, RF, CRP were decreased in patients of both groups after the conducted therapy. It was established a proportionately reliable correction between CRP and LDL levels after treatment in II group of patient $(r=0,63, p<0,05)$.

Conclusions: 1.There is a lack of flow-mediated vasodilation of brachial artery in patients with RA and secondary RS, which can indicate a dysregulation of endothelial function.

2. The level of CRP is increased in patients with RA and secondary RS and is associated with the risk of hyperlipemia and atherosclerosis. 3 . The usage of $\mathrm{NO}$ donators (4,2\% solution of arginine hydrochloride and L-arginine aspartate) in the treatment of RA with secondary RS significantly reduces the levels of IA and IM index, the level of atherogenic lipoprotein fractions (TC, LDL and TG) and decreases the severity of ED, which leads to minimizing the risk of atherogenesis and its complications.

References:

[1] Kuryliszyn-Moskal A, Klimiuk PA, Sierakowski S, Ciolkiewicz M. /A study on vascular endothelial growth factor and endothelin-1 in patients withextraarticular involvement of rheumatoid arthritis // ClinRheumatol. 2006 May; 25 (3): 314-9. 